Коваленко Катерина, учитель зарубіжної літератури, Денишівська ЗОШ I-III ступенів імені В. Г. Бондарчука

\title{
ГІПЕРРЕАЛЬНІСТЬ ПОСТМОДЕРНОГО НАРАТИВУ В РОМАНІ «ПЕРВЕРЗІЯ» ЮРІЯ АНДРУХОВИЧА
}

\begin{abstract}
У статті розглянуто явище гіперреальності в постмодерному романі Юрія Андруховича «Перверзія». Гіперреальність у тексті оприявнена в ефекті «віртуальної», симулятивної реальності. Автор стирае грані між реальним $i$ уявним та створюе умовні світи, котрі переплітаються між собою. Також гіперреальність простежуеться в епізодах, що ілюструють симуляиію стосунків між персонажами роману: нереальність реалъно показаних відносин, де комунікація між людъми не відбуваеться, бо за словами немае дійсної глибини почуттів. Ефект гіперреалъності у постмодерному тексті досягаеться за рахунок того, що сама розповідна стратегія автора спричиняе розмитість межі між фантазією $i$ реальністю, справжнім і симульованим.
\end{abstract}

Ключові слова: постмодернізм, гіперреальність, симулякр, оповідъ, наратор, бокалізачія, дискурс, наративна дистаниіл.

Kovalenko $K$. Hyperreality of the postmodern narrative in the novel Andrukhovich's "Perversion".

The article deals with and interprets the narrative aspects of some episodes of the novel "Perversion" by Yu. Andrukhovich, illustrating the phenomenon of a hyperreality.

The hyperreality is a prominent feature of postmodern creativity. By this concept, it is an idea of the world in which objective reality itself is relative, because the subject is not able to capture the whole reality or to offer it's ideal variant, and generally they do not know what is reality and where it is. Hyperreality in the text is manifested in the effect of "virtual", simulated reality. This phenomenon is vividly represented in selected fragments depicting the same event: the opera Orpheus in Venice. It traces the blurring of the boundaries between the real and the imaginary and the creation of conditional worlds that are intertwined.

According to Bordiard's "Theory of Signs", the events surrounding the opera "Orpheus in Venice" are described on the third and fourth levels of the signs. The presence of the publisher and his preface at the beginning of the novel, the intrinsically focussed story of Stakh Perfetsky masks that there is no corresponding reality behind the events described in the seminar (third-order simulacrum). A pictured action on the stage (fourth order of the simulacrum) also contributes to this. On the background of the chaotic 
staging of the opera, a seminar in Venice is perceived, as not a credible event at least as possible.

The hyperreality is also traced in the episodes that illustrate the simulation of relationships between the characters of the novel: the unreality of real-world relationships where communication between people does not occur because, according to the words, there is no real depth of feelings. The heroine's behavior resonates with her attention to the hero's story. He sincerely talks about the tragedy he has experienced, but there is no confirmation to the truth of this story, because it is a story.

The effect of the hyperreality in the postmodern text is achieved by the fact that the narrative strategy of the author causes a blurring of the boundary between fantasy and reality, true and simulated.

Key words: postmodernism, hyperreality, simulacrum, narrative, narrator, focalization, discourse, narrative distance.

Постановка проблеми. Юрій Андрухович беззаперечно перебуває серед найпомітніших постатей сучасної української літератури. Його твори зазвичай викликають суперечки й дискусії не лише у професійних літературних колах. Оцінки Ю. Андруховича як письменника сягають подекуди діаметрально протилежних полюсів - від «постмодерного скандаліста» до «живого класика». Але найбільше він відомий як один із представників постмодернізму в українській літературі.

Характеризуючи свій роман «Перверзія» в інтерв'ю з Наталкою Білоцерківець, письменник зазначає: «Я - иілковито за дискусію... Будъ ласка, критикуйте мене, розвінчуйте, але будъте в рівні своєї критики адекватними рівневі роману!» [4, с. 27]. Ю. Андрухович вимагає постмодерної критики та відповідного підходу для інтерпретації постмодерного твору.

«Термін «постмодерністъ», що утворений із етимологічно суперечливого сполучення «пост» (після) $i$ «модо» (саме зараз), нині довільно включае в себе чілу низку рухів, іноді несумісних, що виникли в заможних краӥнах Європи в країнах європейсъкого походження в мистецтві, архітектурі, літературі, музиці, в суспільних та гуманітарних науках...» [2, с. 327] - пише Р. Барський.

Я. Кулінська стверджує: «Постмодернізм приніс із собою новий погляд на світ, як на такий, що вже неможливо пізнати $і$ в якому неможсливо створити щосъ нове» [6, с. 9]. На думку Г. Чміль, «смерть Бога (Ф. Нічще) постмодернізм доводить до «логічного» кіния ідё краху реальності» [8, с. 254]. Зауважимо, що «на позначення світу, у якому сама об'єктивна реальність відносна, використовують термін «гіперреальність», який був запропонований франиузъким теоретиком Жаном Бодрійяром для опису умов, за яких імітація або відтворення реальності набувають більшої легітимності, цінності й сили, ніж самі оригінали» [6, с.9]. Гіперреальність є 
58 Літератури світу: поетика, ментальність і духовність. 2020. Bип. 14

прикметною характеристикою постмодерної творчості. Т. Гундорова зазначає, що «... логічно впорядкована реальність, ... мовна свідомість $і$ символічний порядок культури в епоху постмодерну набувають перервного, різноспрямованого, фрагментарного характеру. Такий дискурсивний простір постмодерну гібридний, неіерархічний, позбавлений тяглості, різноспрямований та іонізований. Він визначае характер постмодерної репрезентаціi, яка втрачає рачіональну зв'язність і тотальність, оскільки, по-перше, суб'єкт не спроможний охопити всю реальність або запропонувати її ідеальний варіант, а по-друге, загалом невідомо, що таке реальність $i$ де вона перебуває» [5, с. 13]. У сучасному літературознавстві один із нових підходів до аналізу художнього тексту пропонує наратологія «дослідження наративу як вербального способу представлення часово орієнтованих ситуацій $i$ подій» (Ж. Женетт) [7, с.83]. П.Баррі доводить, що «наратологія не е читанням й інтерпретацією окремих оповідей, вона мае на меті дослідити природу самої «оповіді» як явища та як культурної практики» [3, с. 264], а О. Ткачук підкреслює, що вона «досліджуе проблеми часу, способу й голосу» [7, с. 83].

Аналіз останніх досліджень i публікацій 3 даної теми. Проза Юрія Андруховича втрапляла в коло наукових зацікавлень багатьох дослідників. Розвідки А.Бондар-Терещенка, Я. Голобородька, Т. Гундорової, Н. Зборовської, М. Ільницької, М. Рябчука, Н. Білоцерківець, О. Юрчук та ін. висвітлюють окремі аспекти його творчості, як-от: інтертекстуальність, гра з читачем, співвідношення автора й персонажа, стильова й жанрова еклектика, карнавальність, барокові традиції тощо. Зважаючи на новизну вивчення оповідної стратегії в українському літературознавстві, актуальним видається дослідження наративних аспектів прози Юрія Андруховича в контексті поетики постмодерного твору.

Мета і завдання статті - розглянути й проінтерпретувати наративні аспекти деяких епізодів роману «Перверзія» Ю. Андруховича, що ілюструють явище «віртуальної», симулятивної реальності постмодерного твору.

Виклад основного матеріалу дослідження. У романі письменника гіперреальність проявлена i як стирання граней між реальним та уявним, і як симуляція стосунків чи комунікації. Так, у фрагменті (28) гіперреальність ілюструє несправжність взаємин між Адою та Стахом. Фрагмент є переказом відеокасети, невідомо ким записаної. «Невідома камера, вочевидъ, прихована, прачюе статично, жодної зміни ракурсу протягом усъого відзнятого матеріалу. 
Постійно загальний план» [1, с. 259]. Ада зі Стахом вечеряють, час від часу підходить кельнер. Немає опису думок, відчуттів, це міметична зовнішньо фокалізована оповідь, але слова й жести більш промовисті, ніж найпотаємніші думки.

Ада говорить про почуття: «Я зі страхом чекаю години, коли ми розійдемося...», вимагає від Стаха відвертості: «... майже нічого не знаю про тебе... Пам'ятаєш, тодi, в Сан-Марко, я розказувала тобі про себе. Все, що тобі хотілося знати. До інтимних подробиць (Ада лукавить - К. К.). Але твое життя? Я не знаю про тебе нічого» $[1$, с. 260]. Стах відкриває Аді свою душу, розповідає про найсокровенніше й найболючіше: «... Вона померла. . . ми прожсили з нею неповних n'ять років... я тремтів, коли підходив надто близъко до неї...» [1, с. 263]. 3'являється кельнер, Ада фліртує з ним, вони разом кепкують із Стаха, який цього не помічає і «занурений у власне, продовжуе» [1, с. 263]:

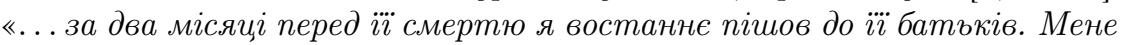
не пустили навіть на поріг...» [1, с. 265].

$\mathrm{y}$ цей час між Адою та кельнером відбувається діалог:

Кельнер. Ви мене кликали, пані?

А. Ц. (Здивовано, зі сміхом) Звідки ви знаєте? Прошу поміняти свічку.

Кельнер. Свічку? (Посміхається). Ця свічка вже не годиться? (косить оком трохи на недогарок, трохи на Стаха). Зараз, пані.

Ада смієтъся з його жарту... [1, с. 265].

Ïї реакція на розповідь Стаха нещира, награна, слова надто пафосні: «але як ти че пережив? Як ти не вмер тоді? Як ти смів лишитися $i$ жити?...» $[1$, с. 266]

Чоловік розповідає страшні речі про себе: «...я лежав горілиць просто на землі, і мені не моглося навіть дихати... Я розламав

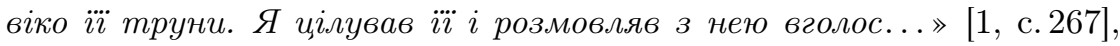
він вже довірився Аді, для неї ж усе це черговий життєвий епізод,

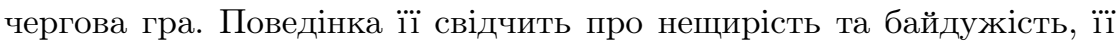
сміх у найтрагічніші моменти Стахової оповіді, розмова з кельнером на невідомій для Стаха мові - яскраве тому підтвердження.

Отже, у фрагменті стерто грані між реальним та симульованим. Тут Адина поведінка (флірт із кельнером) дисонує з її вдаваною увагою до розповіді Стаха - бачимо не оригінали, а копії, однак ані флірт кельнера та Ади, що є лише імітацією справжніх стосунків, ані світська толерантність Ади як слухачки, не претендують на справжність - то є симулякри; з іншого боку, Перфецький щиро розповідає про справжнє, істинне - нібито пережиту ним трагедію, але підтвердження істинності 
60 Літератури світу: поетика, ментальність $і$ духовність. 2020. Bип. 14

цієї історї відсутні - адже це лише його розповідь. Зображене не має справжнього змісту, сприймається як поверхня без глибини.

Феномен гіперреальності яскраво представленийу фрагментах (15), (16), (17), (18), (19), що зображають одну й ту ж подію: оперу «Орфей у Венецї». Фрагмент (15) є лібрето «опери buffa y формі pasticcio на три дї та безліч картин» [1, с. 154] «Орфей у Венеції. Автор лібрето - Метью Кулікофф. У тексті переважає міметичний тип нарації, оповідь має нульову фокалізацію. Автор лібрето - наратор - розгортає перед глядачами-читачами запланований сценарій, за яким далі буде розвиватися дія. Автор зазначає, що «дія відбувається в усі часи $i$ всюди» [1, с. 154]. Лібрето є своєрідним пролепсисом, що стає зрозуміло з наступних фрагментів.

Фрагмент (16) є черговою депешею Ади Монсеньйорові. Вона розповідає про прибуття їі, Респондента (Стаха) і Доктора у театр, де «відбулася одна з найголосніших музичних сенсацій нашого часу, звістка про яку спершу облетіла всю Венецію, а згодом - i решту cвimy» [1, с. 163]. Оповідь переважно міметична, місцями - дієгетична, адже завдання Ади - якнайдетальніше описати вечір та поведінку Респондента. Її розповідь внутрішньо фокалізована, застосовано транспонований дискурс для передачі діалогів. Таким чином, Ада подає картину поведінки та реакцій залу на виставу та особливості постановки очима невтаємниченого глядача: «зовні не надто показний, театр «Ля Феніче» просто спалахуе всередині... [1, с.163], «більшість глядачів була в прерізних масках $i$ фантастичних строях» [1, с. 164], «декорачія являла собою все на світі» [1, с. 165], «увертюра складалася з безлічі інших увертюр, які лягли одна на одну нашаруваннями» [1, с. 165], «сцена була переповнена людом, мішанина одягів аж волала несмаком» [1, с. 165]. Починається дуже дивна вистава, але Ада зазначає, що «кавалки різних опер було припасовано один до одного вельми вдало $i$ непомітно, але навіть неозброєному знанням оперового мистецтва вухові було ясно, якими відвертими нитками шита вся ия матерія» [1, с. 166].

Глядачі відповідно на це все реагують: «niд час речитативів публіка робилася неуважною, жлуктила пепсі $i$ хрускотіла солоними паличками, були й такі, що грали в карти або в доміно - щоби не допустити повного розброду в залі, режисер час від часу влаштовував їм нову несподіванку у вигляді вибуху. . . або люстри, що. . п починала стрімко падати на голови сидячих» [1, с. 166]. Фрагмент обривається на тому місці, де Ада описує замах на Стаха: «у спину йому летів ніж, $i$ куля,...і капсуля з иіяністим калієм, $і$ голка з кураре, $i$ двоє 
гевалів, зодягнутих у шати венеційсъких найманих убивць, підкралися ззаду, щоби його задушити голими руками або шовковим шнурком, або шкіряною шлейкою...» [1, с. 169], але Стах «перемахнув довгими ногами через балкон, вхопився обіруч за натягнуту для «турецького

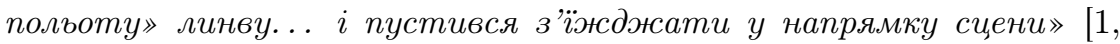
c. 170]. Депеша Ади обривається на словах: «я, можливо, й не мала на че права, але наважилася в такій ситуащї вдатися до засобів» [1, c. 170$]$.

Фрагмент (17) є передрукованою частиною книги «Містер Шок. П'ять монологів Метью Несамовитого». Автор книги, вже згадуваний автор лібрето опери «Орфей у Венецї̈ Мет'ю Кулікофф, розповідає про особливості своїх вистав і творчого процесу: «Для того, аби побачити все чи почути все у мої виставах, треба мати сто пар вух. I будъ-якого іншого органу бажсано мати по сто. Бо я даю тисячі паралельних дійств... Тілъки я на своєму режисерсъкому пульті можу сприймати. . в відсотків так на десять того, що сам задумав...» $[1$, с. 170$]$.

На прем'єрі сталася трагедія: 3 невідомих причин загинуло двоє людей, і режисер намагається прояснити ситуацію (внутрішня фокалізація). Адже він вважає, що свідчення очевидців про події в театрі на прем'єрі вистави «Орфей у Венеції» не можуть бути вичерпними, бо навіть його власне таким не є, але воно «все-таки найповніше».

Режисер розповідає про свої «муки творчості»: «Сума давала змогу робити оперу, якої ще не було. I всупереч цьому я вирішив робити ї з тих опер, які вже були» [1, с. 172], «переслухав близъко n'ятисот опер» [1, с.173], «залишив тих виконавців, котрі спромоглися розуміти, чого я від них добиваюся. Хоч я й сам ивого довгий час не знав...»[1, с. 173]. За три дні перед прем'єрою режисер береться до постановки опери в театрі. Прем'єрі загрожував провал. Але «невідомий молодик», що спустився по линві з балкона четвертого ярусу (місце Стаха Перфецького - K. К.), який «не був підсадним виконавием» і якого вперше бачив режисер, врятував її: «його теплий баритон,... його пластика й міміка..., його здатність блискавично орієнтуватися в перебігові подій на сцені $i$ діяти так, як вимагає того мій задум та моє лібрето, - все ие $i$ стало причиною... майже істеричного успіху» [1, с.177]. Метью Кулікофф каже про героя-імпровізатора визначальну фразу: «Він був перший, хто вніс душу (виділ. Ю.А.) в ию механічну виставу» [1, с.177], що й ілюструється у наступному фрагменті (18). Стах опиняється на сцені. 
Сценічне дійство (міметична оповідь) сприймається ним як реальна ситуація. Розповідь внутрішньо фокалізована. Стах відчуває запахи, звуки, він природно реагує на героїв, однак поведінка його збігається із передбаченими режисером діями. Усе, що відбувалося, описане в минулому часі, хоча вжито цитований дискурс.

Цей фрагмент сприймається як найбільш «достовірний», бо у ньому відсутня наративна дистанція. Розповіді Ади та Кулікоффа мають конкретних нарататорів: Монсиньйор, читач. У фрагменті, що належить Аді, фіксуються усі дії Стаха, також її враження та супутні думки; Кулікофф змальовує себе «неповторного» для вдячних прихильників, для пам'яті нащадків. Усе описане ними сприймається як «механічна вистава» [1, с. 177], як життєвий театр, у якому кожна людина грає свою роль. І лише поява Стахового фрагмента «вселяє душу у цю механічну виставу». Його розповідь «забарвлена», вона передає запахи, відчуття, звуки, людські почуття та емоції.

Проаналізувавши зазначені фрагменти, можемо простежити очевидні паралелі між лібрето [1, с. 154], сценічним дійством та подіями в глядацькому залі. Орфей співвідносний зі Стахом. Внутрішній стан співця Орфея, пережите горе (втрата Еврідіки збігається зі станом Перфецького, що його помітив священик): «I тільки Орфей, запнутий чорним плащем $i$ схований під маскою печалі, не надто тішиться всім, що побачив на чъому прегарному святі. Чорніший від хмари,... ходить він у святковій юрбі, мов неприкаяний грішний дух» $[1$, с. 156]. Поцілунок Стаха й Ади, описаний нею, відбувся після першої дії (як у лібрето), убивство замислюється на початку третьої дії (замах на Стаса, балкон). Відповідно, Аду можна співвіднести з Ріною («... ие не була вона, Ада. Чи Ріна?» [1, с. 186]), Інквізитора - із загадковим Монсиньйором, його радника, наглядача Ріни Асклепіо - 3 Доктором. Прикметно, що під час переміщення Стаха на сцену депеша Ади обривається, а Доктор під час вистави спить (його свідомість не прив'язана до подій у залі).

Невідомо, хто є автором фрагменту (19). Він являє собою дієгетичну зовнішньо фокалізовану оповідь про те, що «писала венеційська преса тих днів». Наративний дискурс не сприяе враженню достовірності, тому інформація про «замах, який готуєтъся на одного з іноземних учасників конференції» [1, с. 191] сприймається як плітки. До речі, вбивство двох акторів (подія, запланована у лібрето, Перфецький же, очевидно, здійснив це реально у виставі) режисер опери пояснив наступним чином: «Bu досі вважаєте мене причетним до тих двох мерців, знайдених після прем'єри...? Що ж, я справді 
причетний! Як причетний кожен добрий митець до вигодуваних ним cuтуацій» [1, с. 178]. За «теорією знаків» Бодрійяра, події навколо опери «Орфей у Венеції описані на третьому й четвертому рівнях знаків. Наявність видавця та його передслова на початку роману, внутрішньо фокалізована оповідь гомодієгетичного інтрадієгетичного наратора (Стаха Перфецького) маскують те, що за описуваними подіями семінару немає відповідної реальності (симулякр третього порядку). Сприяе цьому й зображуване дійство на сцені (симулякр четвертого порядку). На тлі хаотичної постановки опери семінар у Венеції сприймається, якщо не як достовірна подія, то принаймні як можлива. Проникнення Стаха на сцену, паралелі між персонажами сценічного дійства та учасниками семінару $є$ характерною рисою постмодерного зображення дійсності - «відмінність між тим, що е реальне $і$ що симульоване, руйнується: все є моделлю або образом, все е поверхнею без глибини - че гіперреальність (як називае ї Бодрійяр)» [3, с. 107].

Висновки. Отже, наративні особливості досліджуваних епізодів роману Юрія Андруховича «Перверзія» виявляють такий феномен постмодернізму як гіперреальність, що в основі має концепцію «втрати реальності» Ж. Бодрійяра. Гіперреальність виражена в ефекті «віртуальної», симулятивної реальності, стиранні граней між реальним і уявним, а також присутня у епізодах, що ілюструють симуляцію стосунків між персонажами роману. Явище гіперреальності у постмодерному тексті досягається за рахунок того, що сама розповідна стратегія автора спричиняє розмитість межі між фантазією i реальністю. Розгляд наративних особливостей вибраних епізодів доповнює наявні розвідки про особливості постмодерного роману й дослідження художніх особливостей прози Юрія Андруховича. Стаття відкриває перспективи для подальшого дослідження наративних аспектів прози Юрія Андрухович.

\section{Література}

1. Андрухович Ю. Перверзія. Львів : Класика, 2001. 290 с.

2. Барський Р. Постмодерність // Енциклопедія постмодернізму/ за редакцією Ч.Е. Вінквіста та В.Е. Тейлора. Київ : Видавництво Соломії Павличко «Основи», 2003. С. 327-331.

3. Баррі П. Вступ до теорії: літературознавство і культурологія. Київ : Смолоскип, 2008. 360 c. 
64 Літератури світу: поетика, ментальність і духовність. 2020. Bип. 14

4. Білоцерківець Н. Sempero tiro на тлі перверсій і рекреацій. Друг читача. 1997. № 5. С. 26-27.

5. Гундорова Т. Постчорнобильська бібліотека. Український літературний постмодерн. Київ : Критика, 2005. 264 с.

6. Кулінська Я. Гіперреальність у прозі Ю. Андруховича, О. Ірванця та В. Неборака. URL: http: //irbis-nbuv.gov.ua/cgi-bin/ irbis nbuv/cgiirbis 64.exe?C21COM $=2 \& \mathrm{I} 21 \mathrm{DBN}=\mathrm{UJRN} \& \mathrm{P} 21 \mathrm{DBN}$ $=\mathrm{UJRN} \& I M A G E \_\bar{F} I L E \_D O W N L O A D=1 \&$ Image_file_name $=\mathrm{PDF}$ $/ \mathrm{Pl} 2012 \_85 \_4 . p d f$ (дата звернення 14.12.2020).

7. Ткачук О. Наратологічний словник. Тернопіль: Астон, 2002. 173 с.

8. Чміль Г. Симуляційна природа сучасності: фарс чи повільно діюча отрута свідомості? URL: http: //irbis-nbuv.gov.ua/cgi-bin/ irbis_nbuv/cgiirbis 64.exe?C21COM $=2 \& \mathrm{I} 21 \mathrm{DBN}=\mathrm{UJRN} \& \mathrm{P} 21 \mathrm{DBN}$ $=\mathrm{UJR} \bar{R} \& \mathrm{IMAGE}$ FILE_DOWNLOAD $=1 \&$ Image_file_name $=\mathrm{PDF}$ /apmpmn_2010_3_41.pdf (дата звернення 14.12.2020). 